\title{
Peranan dan Sumbangan JAKIM dalam Dialog antara Agama
}

\author{
The Role and Contribution of JAKIM in Interfaith Dialogue
}

\author{
MAHFUZAH ZOHDI*, YUSRI MOHAMAD RAMLI \& JAFFARY AWANG ${ }^{1}$
}

\begin{abstract}
The Department of Islamic Development Malaysia or officially known in its Malay form as Jabatan Kemajuan Islam Malaysia (JAKIM) always been seem to has did a little in participating itself in dialogue between different beliefs. As an authoritative and governmental representative of Islam, JAKIM is craved by the religious societies especially Muslims to be more exposed and championing itself in interfaith dialogue to foster mutual understanding as well as comprehend the societies about Islam and tie up relationship with other religious communities. Therefore its involvement in the Committee for Promoting Understanding and Harmony among Religious Adherents or Jawatankuasa Mempromosikan Persefahaman dan Keharmonian di antara Penganut Agama (JKMPKA) seem to be a big step forward for JAKIM to be more active in dialogue. This case study analyse the role and contribution of JAKIM in interfaith dialogue since its inception till today. This qualitative study collected data by documenting information through interviews and observations as well as studying archive of JAKIM's files and documents relating to the subject. All data then be analysed by using 'Atlas.ti' software to better organise them in classified themes. This study shows that JAKIM did involve in interfaith dialogue albeit limitedly since its early establishment. The programs of interfaith dialogue organised by JAKIM are conducted whether in direct way which is a direct dialogue between religions such as Mosque Tour Guide and interfaith discourses, or indirect way by and large limited to a single religious community but related to interfaith issues such as mission carried by JAKIM to rural areas as well as interfaith course in Muslim College of London. Recent development shows a better development with the participation in JKMPKA although its role is limited as a mediator between Muslim NGOs.
\end{abstract}

Keywords: interfaith dialogue, Islamic authority, JAKIM

Aktiviti dialog antara agama di Malaysia dikatakan telah bermula di negara ini sejak awal tahun 1950-an. Pelaksanaannya pada peringkat awal telah dipelopori oleh The Pure Life Society, sebuah badan kebajikan yang mempromosikan perpaduan kalangan masyarakat pelbagai kaum. Aktiviti dialog yang dilaksanakan pada ketika itu dibuat dalam bentuk ceramah dan forum serta program kebajikan di rumah anak yatim, orang miskin dan ibu tunggal (The Pure Life Society 2013). Persatuan yang didaftarkan dengan nama Persatuan Hidup Murni ini kemudiannya menubuhkan Majlis Kerjasama antara Agama Sedunia (World Council for Inter-Faith

\footnotetext{
${ }^{1}$ Mahfuzah Zohdi*(Corresponding author), Religious Official, Dept. of Islamic Development Malaysia (Jabatan Kemajuan Islam Malaysia), 62519 PUTRAJAYA, and Master Student, Dept. of Theology and Philosophy, Faculty of Islamic Studies, Universiti Kebangsaan Malaysia, 43600 BANGI, Selangor, Malaysia, email: wafi_11@yahoo.com; Yusri Mohamad Ramli, M.A., Lecturer, Dept. of Theology and Philosophy, Faculty of Islamic Studies, Universiti Kebangsaan Malaysia, 43600 BANGI, Selangor, Malaysia, email: yusri_mr@ukm.edu.my; Jaffary Awang, Ph.D., Associate Professor, Dept. of Theology and Philosophy, Faculty of Islamic Studies, Universiti Kebangsaan Malaysia, 43600 BANGI, Selangor, Malaysia, email: jaffary@ukm.edu.my.
} 
Cooperation) yang bergerak aktif sehingga tahun 1962. Pada tahun 1963, ia semakin berkembang dan bergerak dengan menggunakan nama Pertubuhan antara Agama Malaysia (Malaysian Inter-Religious Organisation - MIRO). Walau bagaimanapun, aktivitinya semakin malap sehinggalah pada tahun 1986, ia diberikan nafas baru dengan penubuhan Inter-Faith Spiritual Fellowship (INSaF) (Ahmad Munawar \& Wan Kamal 2012; Arfah 2013; Mustafa Kamal \& Jaffary 2013). Sekitar tahun 1970-an, keterlibatan NGO Islam dalam dialog antara agama masih tidak begitu ketara sehinggalah wujudnya Angkatan Belia Islam Malaysia (ABIM). ABIM yang ditubuhkan pada tahun 1971, dikatakan telah memulakan langkah mengadakan dialog agama antara penganut Islam dan Konfusianisme sekitar tahun 1970-an sejurus selepas penubuhannya (Chih Feng Lum 2001). ABIM turut terlibat dalam seminar-seminar dialog antara agama yang dianjurkan oleh NGO lain. Antaranya pada Oktober 1980, ABIM menyertai satu seminar antara agama yang dianjurkan oleh Young Men Christian Organisation (YMCA) dan Partners of People of Other Faiths (Arfah 2013).

Pada tahun 1992, Institut Kefahaman Islam Malaysia (IKIM) ditubuhkan dengan matlamat penubuhannya untuk memberikan kefahaman yang tepat mengenai Islam kepada seluruh masyarakat (Institut Kefahaman Islam Malaysia 2014). Kini, terdapat beberapa pertubuhan bukan kerajaan (NGO) yang dipelopori oleh orang-orang Islam dan bukan Islam yang berperanan dalam mempromosikan dialog antara agama seperti Akademi Kajian Ketamadunan (Academy of Civillisation Studies), Kolej Darul Hikmah, Islamic Propagation Society (IPSI), International Movement For A Just World (JUST), Malaysia Inter-faith Network (MIN) dan Malaysia Consultative Council for Buddhism, Cristian, Hinduisme, Sikhism and Taoisme (MCCBCHST). Institusi pengajian tinggi tidak terkecuali dalam melaksanakan program dan aktiviti dialog antaranya Jabatan Usuluddin dan Falsafah, Fakulti Pengajian Islam di Universiti Kebangsaan Malaysia (UKM), Pusat Dialog Peradaban di Universiti Malaya (UM) dan Kulliyyah Ilmu Wahyu dan Sains Kemanusiaan di Universiti Islam Antarabangsa Malaysia (UIAM) (Wan Sabri \& Arfah 2012). Di peringkat kerajaan Malaysia, kepentingan terhadap dialog antara agama turut diambil perhatian. Ia dapat dilihat apabila pada 24 Februari 2010, kerajaan telah mewujudkan Jawatankuasa Mempromosikan Persefahaman dan Keharmonian di antara Penganut Agama (JKMPKA) yang antara tujuannya adalah untuk membantu kerajaan mempromosikan persefahaman dan keharmonian antara penganut agama di Malaysia. Keanggotaannya terdiri dari Majlis Tao MCCBCHST, Allied Coordinating Committee of Islamic NGO'S (ACCIN), IKIM, Jabatan Kemajuan Islam Malaysia (JAKIM), Institut Pengurusan dan Penyelidikan Fatwa Sedunia (INFAD) dan Islamic Information and Services Foundation (IIS) (Jabatan Perpaduan Negara dan Integrasi Nasional 2013).

Pertembungan dan konflik yang melibatkan perbezaan agama dan bangsa kerap berlaku dalam sesebuah negara yang mempunyai masyarakat majmuk. Dialog antara agama dipercayai sebagai kaedah terbaik dalam menangani konflik tersebut (Muhammed Fauzi et al. 2009; Nuredayu 2002). Sekiranya dilihat dalam konteks Malaysia, negara ini tidak terkecuali dalam berhadapan dengan isu-isu yang menjejaskan hubungan antara kaum. Ketidakseimbangan politik, sosial dan ekonomi masyarakat telah menyebabkan tercetusnya peristiwa '13 Mei' pada tahun 1969, yang hanya merupakan 'tanda' dari masalah yang telah berakar umbi dalam masyarakat pada ketika itu. Peristiwa ini kemudiannya telah menyebabkan dasar dan polisi berhubung struktur sosial dan ekonomi negara digubal iaitu Dasar Ekonomi Baru (DEB). DEB diperkenalkan pada tahun 1970. Dasar ini mengandungi enam dokumen iaitu Dokumen A: Policies for Growth with Racial Balance, Dokumen B: Racial Disparity and Economic, Dokumen C: The New Economic Policy, Dokumen D: Employment, Production and Racial Economic Balance Targets for the SMP, Dokumen E: Problem of Racial Economic Imbalance and National Unity dan Dokumen F: Social Research for National Unity. Ia dibentuk dengan matlamat untuk meneliti bagaimana kaedah terbaik dalam memastikan perpaduan negara dapat dicapai (Faaland et al. 2005). Walaupun dasar ini memberi kesan positif terhadap pembentukan perpaduan dan sosioekonomi negara, hakikatnya sehingga kini, negara masih berhadapan dengan isu-isu 
perpaduan yang tidak boleh dipandang mudah. Malah, pada ketika ini terdapat pihak yang semakin berani menyuarakan pandangan dan membuat tuntutan, bukan sahaja atas dasar kepentingan sesuatu entiti tetapi turut menyentuh sensitiviti agama dan kaum lain (Amir Hasan 2010).

Hunt (2009) telah merangkumkan empat isu utama yang telah menimbulkan perselisihan dan ketegangan antara kaum dan penganut pelbagai agama di Malaysia. Pertama, isu kebebasan beragama. Seseorang yang beragama Islam, tidak sewenang-wenangnya boleh menukar agamanya kepada agama lain sebagaimana yang telah diperuntukkan dalam Undangundang Syariah di Malaysia. Kedua, meruntuhkan rumah-rumah ibadat agama lain. Penganut agama lain merasakan sukar untuk membina rumah ibadat mereka, malah rumah-rumah ibadat yang sedia ada terpaksa pula dirobohkan, disebabkan pembinaannya atas tanah kerajaan dan tidak mendapat kelulusan Pihak Berkuasa Tempatan. Ketiga, isu tuntutan untuk menggunakan kalimah tertentu yang bersifat bahasa Arab oleh penganut agama lain selain Islam, sedangkan kalimah tersebut terlalu sinonim dengan Islam sahaja. Contohnya adalah seperti kalimah 'Allah', 'Kaabah', 'Baitullah' dan 'solat'. Dan isu keempat, adalah larangan penggunaan kalimah 'Allah' di dalam Bible kerana ia boleh mengundang kekeliruan bagi umat Islam.

Dalam isu-isu yang dinyatakan di atas, Hunt (2009) berpandangan bahawa dialog antara pelbagai agama dapat memberi kefahaman kepada penganut agama lain berhubung permasalahan yang timbul. Walau bagaimanapun, beliau turut berpandangan, terdapatnya sebilangan pihak yang mendakwa bahawa dialog antara agama hanyalah membuka ruang kepada pihak lain untuk menyerang Islam serta meletakkan agama Islam setaraf dengan agamaagama lain. Pihak-pihak sedemikian dianggap cuba menutup ruang dalam bekerjasama dengan penganut-penganut agama lain. Adakah tanggapan ini benar? Adakah isu-isu yang dinyatakan di atas boleh diselesaikan di meja dialog kerana ia menyentuh urusan dasar dan polisi negara. Sekiranya dialog antara agama diadakan, adakah ia memberi signifikan dalam hubungan antara penganut pelbagai agama? Justeru, pada pandangan kajian ini, adalah penting konsep dialog antara agama perlu difahami dengan betul, serta ditentukan dalam bentuk yang bagaimana ia perlu dilaksanakan dalam konteks negara ini.

Fenomena dialog antara agama sebenarnya bukan suatu yang asing lagi bagi negaranegara seperti United Kingdom, Amerika Syarikat, Australia dan seumpamanya yang mempunyai penghijrah yang ramai dari negara lain. Dalam negara-negara ini, masyarakat Islam merupakan golongan minoriti, namun aktiviti-aktiviti dialog sering diadakan dengan kerjasama pertubuhan-pertubuhan bukan kerajaan yang mewakili agama masing-masing seperti Yahudi, Kristian dan Islam, serta mendapat kerjasama daripada pihak kerajaan dan Pihak Berkuasa Tempatan (Liyatakali 2004). Dalam konteks Malaysia pula, ia menunjukkan corak yang sama iaitu aktiviti dialog antara agama dipelopori oleh badan bukan kerajaan. Di pihak kerajaan, ia dimulakan dengan melibatkan IKIM dan JAKIM. Usaha ini dikatakan mencapai tahap nasional apabila JKMPKA dibentuk. Penglibatan JAKIM dalam JKMPKA dilihat sebagai penting. JAKIM selaku agensi agama peringkat Persekutuan mempunyai kapasiti untuk bertindak dalam perkara-perkara yang berkaitan dengan penyelarasan dan pembangunan hal ehwal Islam di negara ini. JAKIM juga merupakan urus setia kepada Majlis Kebangsaan bagi Hal Ehwal Ugama Islam (MKI), sekali gus dianggap sebagai rujukan utama dalam masalah-masalah berkaitan Islam dan umat Islam (Urusetia Majlis Kebangsaan bagi Hal Ehwal Ugama Islam Malaysia 2013). Oleh itu, apabila isu-isu sensitif berkaitan Islam seperti hak untuk keluar dari agama Islam, pembinaan rumah ibadat, tanah kubur, penggunaan kalimah 'Allah' dalam Bible dan pelaksanaan Undang-undang Jenayah Syariah ditimbulkan oleh sebilangan NGO bukan Islam, maka masyarakat meletakkan harapan agar JAKIM berperanan dan terkehadapan dalam menangani isu-isu ini (Khairulnizam 2005). Sehubungan itu, penglibatan pihak JAKIM dalam JKMPKA merupakan langkah penting kepada JAKIM untuk lebih berperanan dalam dialog antara agama. Ia juga dilihat sebagai satu kesempatan buat pihak JAKIM untuk memberi penjelasan berkenaan agama Islam, serta menjalin hubungan dengan penganut agama lain. Namun, 
semenjak penubuhan JAKIM, sejauh manakah pihak tersebut memainkan peranan penting dalam aktiviti-aktiviti dialog antara agama sama ada di peringkat JAKIM sendiri mahupun melalui agensi-agensi di bawahnya, sehingga telah mendorong kajian ini untuk menganalisisnya.

Terdapat beberapa kajian yang telah dibuat berhubung institusi yang ada melaksanakan dialog antara agama, sama ada ke atas pihak kerajaan mahupun badan bukan kerajaan (NGO) yang berada di dalam dan di luar negara. Antaranya adalah kajian yang dilakukan oleh Khairulnizam (2005) mengenai peranan dan aktiviti dialog antara agama yang dilaksanakan oleh INSaF dan Pusat Dialog Peradaban, Universiti Malaya. Beliau merumuskan, badan organisasi dan masyarakat bukan Islam lebih peka terhadap kepentingan dialog antara agama berbanding dengan organisasi dan masyarakat Islam. Beliau turut mencadangkan supaya pihak JAKIM bertindak sebagai leading organization dalam merancang dan melaksana pelan tindakan, bagi memberi kesedaran dan mempergiatkan lagi aktiviti dialog antara agama di kalangan masyarakat Islam.

Kajian Yusri (2007) pula menjelaskan mengenai perkembangan dialog antara agama di negara ini. Pada peringkat awal selepas kemerdekaan Malaysia, aktiviti dialog antara agama dipromosikan oleh badan bukan kerajaan yang dianggotai oleh masyarakat bukan Islam yang kemudiannya mempunyai keahlian dalam kalangan masyarakat Islam. Di peringkat kerajaan, agensi yang melaksanakan aktiviti dialog antara agama antaranya adalah IKIM, Pusat Dialog Peradaban Universiti Malaya, JKMPKA dan JAKIM. Penekanan aktiviti adalah berkaitan isu-isu sosial yang memerlukan tindakan semua penganut agama. Selain itu, kajiannya turut menekankan kepentingan dialog antara agama sebagaimana yang dianjurkan al-Quran. Malah umat Islam sebenarnya dikenali sebagai pelopor kepada aktiviti-aktiviti dialog, dan perkara ini diperakui oleh sarjana Barat sendiri seperti Eric J. Sharpe, Bruce Lawrence, David Thomas dan Montgomery Watt.

Di negara-negara luar yang umat Islam merupakan golongan minoriti, aktiviti dialog antara agama dianjurkan oleh badan-badan berbentuk NGO yang didukungi oleh komuniti Muslim setempat. Sebagai contoh, dalam kajian Huda (2006), beliau menjelaskan mengenai usaha pihak NGO Islam di Amerika Syarikat memberi kefahaman yang betul mengenai Islam melalui dialog antara agama terutamanya selepas peristiwa serangan 'Sebelas September' (11/9). Antara yang aktif adalah Islamic Society of North America (ISNA), Zaytuna Institute, American Society for Muslim Advancement (ASMA), Muslim Public Affairs Council (MPAC), Council on American Islamic Relations (CAIR), American Muslim Alliance (AMA), Center for the Study of Islam and Democracy (CSID) dan Free Muslim Coalition (FMC). Pendekatan dibuat melalui bengkel, forum, konvensyen dan aktiviti-aktiviti kemasyarakatan dalam pelbagai bidang seperti politik, pendidikan, keagamaan, isu-isu sosial dan hak asasi manusia. Walau bagaimanapun, pendekatan ISNA dalam menganjurkan program dialog antara agama yang disertai dengan aktiviti-aktiviti kebajikan dikatakan paling berjaya mengintegrasikan Islam dengan sosiobudaya masyarakat di Amerika.

Kewujudan polisi dan dasar berkaitan masyarakat majmuk adalah penting dalam sesebuah negara. Dalam kajian Christina Ho (2007), beliau menyatakan bahawa kerajaan Australia telah mewujudkan polisi dan dasar berhubung masyarakat majmuk. Polisi tersebut yang digubal pada tahun 2004 telah mewujudkan, malah mempromosikan manual aktiviti dialog antara agama untuk dilaksanakan oleh masyarakat setempat. Pihak kerajaan melalui Department of Immigration and Multicultural Affairs (DIMA) turut menyalurkan sumbangan kewangan bagi membiayai aktiviti dialog antara agama. Contohnya pada 2003, DIMA telah menyalurkan sebanyak AUD50,000 (Dolar Australia) bagi program sambutan perayaan Eid elFitr, Chanukah dan Orthodox yang melibatkan generasi muda Muslim, Kristian dan Yahudi. Dua tahun berikutnya, dana yang diperoleh meningkat kepada AUD100,000 bagi meningkatkan kerjasama antara NGO Muslim, Kristian dan Yahudi dalam berkongsi kepelbagaian perspektif 
bagi isu-isu semasa seperti dadah, alkohol, keganasan rumah tangga dan warga yang tiada rumah (seperti golongan gelandangan).

Dalam kajian oleh Schottmann (2013), beliau menjelaskan bahawa Australia merupakan antara contoh negara yang berjaya membentuk masyarakat majmuk. Selain ia berkait dengan dasar pihak kerajaan terhadap masyarakat pelbagai bangsa dan agama (Moran 2011), kejayaan ini dibantu oleh peranan yang dimainkan oleh NGO-NGO. Salah satunya adalah Jewish Christian Muslim Association (JCMA). JCMA yang terdiri daripada 3 kumpulan agama terbesar di Australia iaitu Yahudi, Kristian dan Islam, telah bergiat aktif dalam menganjurkan aktiviti-aktiviti dialog antara agama seperti forum, seminar dan persidangan. Program lawatan dan penerangan turut diadakan di sekolah-sekolah. Berbeza dengan sesetengah NGO yang terlibat dalam aktiviti polisi dan dasar negara, JCMA hanya menumpukan kepada isu-isu sosial yang bersifat sejagat seperti perlindungan hak asasi manusia, menangani gejala rasuah, motivasi, pembangunan dan alam sekitar. Apa yang menarik, tiga perkara yang diberi penekanan untuk memastikan hubungan baik dalam JCMA adalah sikap saling menghormati di kalangan mereka yang terlibat dalam sesi dialog, tidak memaksa seseorang yang berlainan kefahaman untuk mengikuti apa yang dianutinya, dan yang terakhirnya adalah bersikap neutral terhadap masyarakat Yahudi, Kristian dan Islam yang terlibat dalam konflik di luar negara.

Terdapat juga negara Islam yang telah mengambil inisiatif melaksanakan dialog antara agama. Mengikut kajian Alhomoudi (2010), penubuhan King Abdul Aziz Centre for National Dialogue oleh Putera Mahkota bagi kerajaan Arab Saudi, antaranya adalah bertujuan untuk memastikan hak-hak beragama bagi golongan minoriti dapat diberikan perhatian. Sekiranya negara-negara lain banyak mengadakan aktiviti bengkel, seminar dan konvensyen yang disertai oleh pelbagai bangsa dan penganut agama, namun pusat ini pula menumpukan perhatian untuk membentuk pelatih dan individu yang berkemahiran dalam dialog antara agama, di samping mengadakan program-program seminar dan konvensyen. Dalam kajiannya juga, Alhomoudi turut menjelaskan bahawa antara masalah yang dihadapi dalam berdialog adalah 'kesangsian persepsi' terhadap dialog dan kurangnya ilmu atau pengetahuan mengenai dialog antara agama terutamanya di kalangan masyarakat Islam.

\section{Metode Penyelidikan}

Kajian ini menggunakan reka bentuk kajian kes dengan pendekatan kualitatif iaitu melalui pengumpulan data secara dokumentasi berdasarkan instrumen temu bual dan pemerhatian. Instrumen temu bual tersebut bersifat semi struktur, walaupun kajian ini mempunyai satu set soalan yang telah dibina, namun ia bebas untuk mengemukakan soalan-soalan tambahan untuk mendapatkan maklumat lanjut berhubung tajuk kajian. Temu bual dilakukan secara bersemuka dengan responden serta direkod dan dicatat. Di samping itu, kajian ini juga merupakan kajian arkib terhadap dokumen-dokumen berkaitan. Ia termasuklah Minit Mesyuarat Jawatankuasa Mempromosikan Persefahaman dan Keharmonian di antara Penganut Agama, Minit Mesyuarat Jawatankuasa Kerja Acara Bersama Pemimpin Masyarakat dan Mesyuarat Penyelarasan Program Kembara Muhibah Sempena World Interfaith Harmony 2013, Laporan-laporan Tahunan JAKIM dan masjid-masjid serta takwim aktiviti dan laporan-laporan aktiviti yang berkaitan. Analisis data adalah menggunakan kaedah deskriptif. Perisian 'Atlas.ti' digunakan untuk memudahkan penganalisaan berdasarkan tema-tema tertentu iaitu peranan, aktiviti dan sumbangannya. Walau bagaimanapun, kajian untuk artikel ini hanya memfokuskan kepada Jabatan Kemajuan Islam Malaysia (JAKIM). Ia turut merangkumi beberapa bahagian dan institusi yang berada di bawah JAKIM yang terlibat dengan aktiviti-aktiviti berkaitan dengan dialog antara agama seperti Masjid Tuanku Mizan Zainal Abidin, Masjid Putra, dan Masjid Wilayah Persekutuan. 
Dari segi pemilihan responden, kajian ini menggunakan kaedah 'persampelan bertujuan' (purposive sampling) iaitu sekumpulan subjek yang mempunyai ciri-ciri tertentu dipilih bagi tujuan temu bual. Ia dibahagikan kepada dua kumpulan iaitu individu yang bekerja di JAKIM yang terlibat dalam perancangan dan pelaksanaan dialog, serta individu yang berada di luar JAKIM tetapi ada hubungan dan kaitan dengan pelaksanaan JAKIM sebagai agensi yang melaksanakan dialog antara agama. Ini bertujuan supaya data mengenai peranan dan sumbangan JAKIM dalam dialog antara agama dapat diperoleh dan dianalisis dengan tepat.

\section{Peranan JAKIM dalam Dialog antara Agama.}

Berdasarkan penelitian melalui dokumentasi dan kajian arkib yang dilakukan, kajian ini merumuskan beberapa perkara berhubung peranan JAKIM dalam dialog antara agama di Malaysia. Peranan JAKIM dalam dialog antara agama boleh dikategorikan kepada dua bentuk iaitu secara langsung dan tidak langsung. Penglibatan secara langsung bermula apabila JAKIM dilantik selaku ahli jawatankuasa JKMPKA. Mesyuarat pertama JKMPKA yang diadakan pada 6 April 2010, telah dihadiri oleh beberapa pertubuhan dan agensi kerajaan iaitu Jabatan Perpaduan Negara dan Integrasi Nasional (JPNIN), IKIM, MCCBCHST, ACCIN dan wakil-wakil dari Sabah dan Sarawak termasuklah JAKIM (Othman 2014). Penglibatan JAKIM secara tidak langsung pula, dikatakan telah bermula awal iaitu semenjak penubuhan JAKIM lagi. Namun, ia tidak dinamakan sebagai 'dialog antara agama' kerana program-programnya dilaksanakan berdasarkan kepada tiga kategori. Pertamanya adalah melalui aktiviti program 'Dakwah Bil Hal'. Ia adalah satu mekanisme untuk menghubung tali persaudaraan sesama manusia sama ada di kalangan umat Islam ataupun bukan Islam. Aktiviti dakwah ini diurus selia oleh Bahagian Dakwah melalui Cawangan Dakwah Khas, dan telah dilaksanakan semenjak awal kewujudan cawangan ini sehinggalah sekarang. Aktivitinya lebih menumpukan kepada komuniti orang asli dan minoriti melalui aktiviti Ziarah Dakwah, Kursus Keluarga Bahagia, Majlis Berbuka Puasa serta program ziarah pesakit hospital (Jabatan Kemajuan Islam Malaysia 2008).

Kedua, memberi pendedahan kepada pegawai-pegawai terhadap hubungan dengan penganut agama lain melalui Kursus Khas Pegawai Hal Ehwal Islam di Muslim College, London. JAKIM telah menjalinkan kerjasama dengan Muslim College dalam penghantaran pegawaipegawainya melalui program Kursus Khas Pegawai Hal Ehwal Islam di kolej tersebut. Ia telah bermula semenjak tahun 1989 hinggalah kini. Program ini telah diadakan dalam dua bentuk iaitu pembelajaran dalam bilik kuliah dan aktiviti luar seperti lawatan, perjumpaan, dialog, aktiviti sosial dan kebajikan. Subjek yang menjadi fokus dalam program ini ialah Kaunseling, Ekonomi dan Kewangan Islam, Dialog antara Agama di United Kingdom, Pertubuhan Sosial dan Kebajikan Islam di United Kingdom, Agama-agama Dunia dan Dunia Islam dan Gerakan-gerakan Islam (Jabatan Kemajuan Islam Malaysia 2009). Jadual 1 sebagaimana di bawah menunjukkan jumlah penghantaran pegawai-pegawai JAKIM ke Muslim College, London bagi tujuan kursus yang dimaksudkan (Bahagian Pembangunan Insan 2014):

\begin{tabular}{|c|c|c|}
\hline Bil. & Tahun & Jumlah \\
\hline 1. & 1989 & 6 \\
\hline 2. & 1990 & 6 \\
\hline 3. & 1991 & 11 \\
\hline 4. & 1992 & 10 \\
\hline 5. & 1993 & 9 \\
\hline 6. & 1994 & 9 \\
\hline 7. & 2002 & 15 \\
\hline 8. & 2003 & 13 \\
\hline 9. & 2005 & 10 \\
\hline 10. & 2006 & 10 \\
\hline
\end{tabular}




\begin{tabular}{|c|c|c|}
\hline 11. & 2007 & 11 \\
\hline 12. & 2008 & 9 \\
\hline 13. & 2009 & 9 \\
\hline 14. & 2010 & 10 \\
\hline 15. & 2011 & 11 \\
\hline 16. & 2012 & 10 \\
\hline 17. & 2013 & 11 \\
\hline 18. & 2014 & 10 \\
\hline
\end{tabular}

Jadual 1: Kursus Khas Pegawai Hal Ehwal Islam di Muslim College, London

Ketiga, melalui tadbir urus masjid di Malaysia. Dalam Pelan Strategik 2009 - 2014, JAKIM telah menyenaraikan pemerkasaan berbentuk pengimarahan institusi masjid, sebagai salah satu kaedah program penerangan mengenai Islam. Program ini dibuat dengan kerjasama Islamic Outreach ABIM (IOA) di masjid-masjid utama seliaan JAKIM iaitu Masjid Negara, Masjid Putra dan Masjid Tuanku Mizan Zainal Abidin. Matlamat utamanya adalah memperkenalkan keindahan Islam kepada penganut agama lain sama ada dari dalam dan luar negara melalui institusi masjid (Jabatan Kemajuan Islam Malaysia t.th.). Program yang dikenali sebagai Mosque Tour Guide (MTG) ini mula dilaksanakan pada tahun 2003 (Islamic Outreach ABIM 2014) dan mulai aktif di masjid-masjid utama seliaan JAKIM sejak tahun 2010 (Normah 2014). Pelaksanaan program MTG diperkukuhkan lagi apabila pada tahun 2010, JAKIM dengan kerjasama ABIM melancarkan Garis Panduan Pelancongan dan Ziarah Masjid oleh Shahabudin Yahya yang mewakili Menteri di Jabatan Perdana Menteri, Jamil Khir Haji Baharom yang dibuat sempena Konvensyen Kesedaran Dakwah Melalui Pelancongan Masjid (Jabatan Kemajuan Islam Malaysia 2010). Bagi Masjid Negara pula, semenjak tahun 2008 lagi dengan kerjasama IOA telah menerbit dan mengedarkan sebanyak 33 tajuk risalah dalam bahasa Inggeris, Sepanyol, Mandarin dan Jepun untuk diedarkan kepada pelancong yang datang. Antara tajuk-tajuk risalah termasuklah Prayer In Islam, Who Is Allah, Becoming Muslim, Why Can't I Pray My Way, Belief in One God, Too Late For Tears, Sharing and Living Islam, 20 Most Common Questions about Islam dan sebagainya (Jabatan Kemajuan Islam Malaysia 2008).

\section{Sumbangan JAKIM dalam Dialog antara Agama}

Peranan JAKIM berhubung aktiviti-aktiviti dialog antara agama memberikan kesan yang cukup mendalam dari sudut sumbangannya. Berdasarkan kajian yang berasaskan kepada dokumen arkib dan pandangan pelbagai pihak yang telah ditemu bual, dapatlah dirumuskan kepada beberapa perkara. Pertama sekali, penglibatan pihak JAKIM dalam dialog antara agama merupakan peluang terbaik untuk berdakwah, malah potensinya adalah sangat besar bagi memberikan kefahaman kepada masyarakat bukan Islam mengenai Islam. Menurut Azizan Baharuddin (2014): “. . dialog ni kalau kita faham 'is silent' dakwah ... 'Dakwah bil hal' . . dan dialog ini adalah wadah kita menyampaikan mesej Islam tu. Kalau kita tengok dalam surah Yasin. .. beritahulah mereka, nenek moyang mereka apa yang belum diberitahu. Tentang apa? Tentang Islam. ..". Katanya lagi: "Selagi kita tiada dialog tiada pemberitahuan . .. Dakwah ini adalah salah satu tanggungjawab JAKIM". Hal ini dilihat bertepatan dengan apa yang dinyatakan dalam alQuran, Surah al-Nahl (16:125) yang bermaksud: "Serulah ke jalan Tuhanmu (wahai Muhammad) dengan hikmah kebijaksanaan dan nasihat pengajaran yang baik dan berbahaslah dengan mereka (yang engkau serukan itu), dengan cara yang lebih baik, sesungguhnya Tuhanmu Dialah jua yang lebih mengetahui akan orang yang sesat dari jalannya, dan Dialah jua yang lebih mengetahui akan orang-orang yang mendapat hidayah petunjuk".

Kedua, dialog dapat menangkis salah faham dan tuduhan-tuduhan terhadap Islam. Sekiranya pihak JAKIM aktif dalam dialog antara agama, ia akan dapat menyelesaikan banyak salah faham mengenai Islam serta menyangkal tuduhan-tuduhan oleh masyarakat bukan Islam berhubung sesuatu isu. Menurut Azizan Baharuddin (2014): "Mungkin, jika dialog ini adalah 
aktif dipromosikan oleh JAKIM, ia akan boleh melenturkan banyak masalah. Contohnya, tuduhantuduhan, tohmahan-tohmahan seperti berebut mayat, ... seperti bila dua orang pasangan bila salah seorang masuk Islam dan pasangan berebut anak... ". Bagi rumusan yang ketiga, sumbangan JAKIM adalah dapat membina hubungan baik dan menunjukkan sifat keterbukaan antara penganut pelbagai agama. Ini dapat dilihat dalam satu Majlis Berbuka Puasa yang dengan kerjasama Masjid Tuanku Mizan, Islamic Outreach ABIM dan Friendship Group Inter Religious Service (FGIS - sebuah NGO yang dianggotai oleh ABIM, Council of Churches (CCM), Buddhist Maha Vihara, Malaysia Hindu Sangam dan Malaysian Gurdwaras Council). Dalam pertemuan tersebut, G. Suresh Kumar selaku Presiden kepada Sathya Sai Baba Council telah berkata bahawa: "Non-Muslim have told me they find it difficult to come visit mosques and engage with Muslims, so we are trying to facilitate this... We get to bask in the beautiful, excellent architecture of the mosque and learn more about this peaceful religion. It's about inclusion and being a part of the community". Menurutnya lagi program sebegini membantunya untuk melihat Islam dalam konteks yang sebenar: "Islam in the truest sense of the religion". Yang keempat, masyarakat bukan Islam dapat melihat sendiri bagaimana sesuatu amalan ibadah dalam Islam dilaksanakan. Dalam majlis yang sama, salah seorang peserta iaitu Thai Ming Yeow berkata: "It really gives me a better understanding of Muslims. Usually we just watch on TV how they perform their prayers, and now I get to experience it first-hand" (Anisah 2014). Difahamkan juga bahawa pihak FGIS telah mengumpul dan menyerahkan sejumlah dana kepada pihak masjid sebagai menunjukkan sokongan dan solidariti kepada Gaza (Ahmad Fahmi 2014). Ini membuktikan bahawa peranan masjid kini bukan sahaja sebagai rumah ibadah, malah telah diperluaskan dengan aktiviti kemasyarakatan serta usaha bagi memupuk persefahaman dan perpaduan antara kaum (Ahmad Nawawi et al. 2004).

\section{Resolusi}

Kajian ini mencadangkan agar lebih banyak lagi kajian lanjutan dilakukan terhadap badanbadan lain terutamanya yang bertindak secara langsung dalam mengurus, menyelaras dan mengendali aktiviti-aktiviti dialog antara agama di Malaysia. Penglibatan pihak kerajaan juga secara langsungnya menggambarkan keprihatinan dari sudut kesinambungan perpaduan dan keharmonian negara ini untuk jangka masa panjang. Justeru, kajian-kajian berkenaan mekanisme, isu-isu yang dibincangkan dan garis panduan adalah perlu untuk memantapkan lagi pelaksanaan dialog antara agama. Hasil kajian mendapati, beberapa cadangan untuk masa akan datang yang mungkin boleh diketengahkan oleh pihak-pihak tertentu terutama sekali JAKIM. Antaranya:

- Memantapkan lagi perancangan dan penyelarasan dialog antara agama. Mekanisme dialog perlu diwujudkan bagi memastikan pelaksanaan dialog antara agama yang diurus selia oleh pihak JAKIM dapat berjalan dengan lancar.

- Perlunya kerjasama yang erat dengan kumpulan pakar sama ada dari kalangan institusi pengajian tinggi, badan-badan kerajaan atau badan bukan kerajaan (NGO) yang terlibat dalam dialog terutamanya bagi menyediakan TOR JAKIM dalam dialog dan garis panduan yang berkaitan.

- Perlunya pihak JAKIM menyedia dan membina kepakaran serta latihan di peringkat dalaman JAKIM sendiri. Sekiranya dialog antara agama merupakan salah satu kaedah dakwah, maka peluang berdialog wajar dipertingkatkan supaya Islam dapat dipersepsikan dengan pandangan yang betul. Ini membantu penganut bukan Islam memahaminya dengan baik serta mampu mengelakkan salah tanggapan terhadap ajaran Islam.

- Pelaksanaan MTG dilihat sebagai berpotensi besar dalam menyebarluaskan perkongsian mengenai keindahan Islam kepada pelawat yang datang sama ada dari dalam dan luar 
negara. Rata-rata pelawat yang berkunjung menzahirkan kekaguman terhadap seni bina Islam yang ditonjolkan melalui masjid di samping mendapat pengetahuan baru mengenai maklumat Islam seperti falsafah dan tertib solat, konsep kenabian menurut Islam dan sebagainya. Justeru, pelaksanaan dan keperluan MTG mungkin boleh ditambah baik dan diselaraskan dengan masjid-masjid utama seliaan JAKIM yang lain. Hubungan erat antara JAKIM, pengurusan masjid dan NGO pengendali MTG perlu dikekalkan. Kajian ini juga mendapati bahawa antara aspek yang masih boleh dipertingkatkan adalah dari segi bantuan dana dan latihan (terutamanya kemahiran berkomunikasi dan menguasai pelbagai bahasa seperti Inggeris, Mandarin dan Arab). Di samping itu, perlunya ada ramai petugas tetap ataupun sukarela, manakala penyediaan statistik dan laporan MTG diharap dapat diperkemaskan secara yang lebih sistematik dan tersusun. Sekiranya site office khusus bagi kerja-kerja perancangan, penyelarasan dan pelaksanaan MTG dapat diwujudkan di masjid-masjid, kualiti pelaksanaannya pasti akan lebih kemas dan berkesan.

Sebagai kesimpulan, didapati pihak JAKIM telah pun memainkan peranan cukup penting secara tidak langsungnya dalam aktiviti-aktiviti dialog antara agama, berbanding secara langsung. Ia boleh dilihat melalui pelbagai aktiviti seperti pertemuan dan ziarah ke atas masyarakat orang asli, 'Dakwah Bil Hal' dan mengimarahkan masjid melalui program 'Mosque Tour Guide'. Penglibatannya dalam JKMPKA merupakan langkah penting JAKIM untuk terlibat secara langsung dalam program-program dialog bersama ketua-ketua agama lain di Malaysia. Ia berupaya memberikan gambaran positif mengenai Islam yang sifatnya rahmat kepada seluruh alam.

\section{References}

Al-Qur'an Mushaf Malaysia dan Terjemahan. 1994. Cetakan ke-4. Shah Alam: Yayasan Restu. Ahmad Fahmi Mohd Samsudin. 2014. Interview, 13 August.

Ahmad Munawar Ismail \& Wan Kamal Mujani. 2012. Themes and issues in research on interfaith and inter-religious dialogue in Malaysia. Advances in Natural and Applied Sciences 6(6): 1001-1009.

Ahmad Nawawi Yaakob, Sidek Abdullah \& Zalaluddin Sulaiman. 2004. Institusi Masjid dan peranannya ke arah membina toleransi beragama dalam masyarakat majmuk. Dlm. Ahmad Sunawari Long, Jaffary Awang \& Kamaruddin Salleh (pnyt.). Islam: Past, Present and Future, hlm. 921-931. Bangi, Selangor: Jabatan Usuluddin dan Falsafah, Fakulti Pengajian Islam, Universiti Kebangsaan Malaysia.

Alhomoudi, Fahad A. 2010. Muslim-Christian relationship from the perspective of King Abdullah's Interfaith Dialogue initiatives: Current challenges and possibilities. Journal of Ecumenical Studies 45(2): 288-295.

Amir Hasan Dawi. 2010. Kepentingan identiti dan perjuangan etnik dalam masyarakat Malaysia. Kertas kerja Persidangan Antarabangsa Minoriti dan Majoriti: Bahasa, Budaya dan Identiti. Anjuran Universiti Pendidikan Sultan Idris. Kuching, Sarawak, 23-24 November.

Anisah Shukri. 2014. In Ramadhan, interfaith ties bloom despite extremist voices at the fringe. http://www.themalaysianinsider.com/malaysia/article/in-ramadan-interfaith-tiesbloom-despite-extremist-voices-at-the-fringe. [5 October 2014].

Arfah Ab Majid. 2013. Inter-religious dialogue in Malaysia and prejudice reduction: A preliminary survey. Proceeding of the International Conference on Social Research, hlm. 706-717.

Azizan Baharuddin. 2014. Interview, 20 August.

Bahagian Pembangunan Insan, JAKIM. 2014. Maklumat statistik kursus khas Pegawai Hal Ehwal Islam di Muslim College, London 1989 - 2014. 
Chih Feng Lum. 2001. ABIM: 3 Dekad yang Penuh Dugaan. Kuala Lumpur: Angkatan Belia Islam Malaysia.

Christina Ho. 2007. 'A Christian, a Muslim and a Jew walk into a room ...' : Inter-faith dialogue and the desecularisation of Australian multiculturalism. Proceeding of Everyday Multiculturalism Conference of the CRSI, hlm. 1-10.

Faaland, J., Parkinson, J. \& Rais Saniman. 2005. Dasar Ekonomi Baru: Pertumbuhan Negara dan Pencapaian Ekonomi. Kuala Lumpur: Utusan Publication.

Huda, Qamar-ul. 2006. Conflict prevention and peace-building efforts by American Muslim organisations following September 11. Journal of Muslim Minority Affairs 26(2): 187203.

Hunt, Robert. 2009. Can Muslim engage in interreligious dialogue? A study of Malay Muslim identity in contemporary Malaysia. The Muslim World 99(4): 581-607.

Institut Kefahaman Islam Malaysia. 2014. Pengenalan. http://www.ikim.gov.my/index.php/ms/info-korporat/maklumat-asas/pengenalan. [27 August 2014].

Islamic Outreach ABIM. 2014. Program Dakwah Pelancong Masjid (Mosque Tour Guide - MTG). http://www.ioacentre.com/index.php/2014-03-17-04-04-53/program-dakwahpelancong-masjid-masjid-tour-guide-mtg. [19 August 2014].

Jabatan Kemajuan Islam Malaysia. 2008. Laporan Tahunan 2008. Putrajaya: Jabatan Kemajuan Islam Malaysia.

Jabatan Kemajuan Islam Malaysia. 2009. Laporan Tahunan 2009. Putrajaya: Jabatan Kemajuan Islam Malaysia.

Jabatan Kemajuan Islam Malaysia. 2010. Laporan Tahunan 2010. Putrajaya: Jabatan Kemajuan Islam Malaysia.

Jabatan Kemajuan Islam Malaysia. t.th. Pelan Tindakan Strategik JAKIM 2009 - 2014. Putrajaya: Jabatan Kemajuan Islam Malaysia.

Jabatan Perpaduan Negara dan Integrasi Nasional. 2013. Latarbelakang. http://www.jpnin.gov.my/objektif_jkmpka. [22 November 2014].

Khairulnizam Mat Karim. 2005. Realiti aplikasi dialog antara Agama di Malaysia: Kajian terhadap Inter-Faith Spiritual Fellowship (INSaF) dan Pusat Dialog Peradaban, Universiti Malaya. Tesis Ijazah Sarjana, Jabatan Akidah dan Pemikiran Islam, Universiti Malaya.

Liyatakali Takim. 2004. From conversion to conversation: Interfaith dialogue in post 9-11 America. The Muslim World 94(3): 343-355.

Moran, Anthony. 2011. Multiculturalism as nation-building in Australia: Inclusive national identity and the embrace of diversity. Ethnic and Racial Studies 34(12): 2153-2172.

Muhammed Fauzi Othman, Mohd Koharuddin Balwi \& Mohd Azhar Abdul Hamid. 2009. Globalisasi dan hubungan etnik. Hubungan Etnik di Malaysia: Perspektif Teori dan Praktik. http://eprints.utm.my/14545/1/MuhammadFauziOthman2009_Globalisasidan HubunganEtnik.pdf. [22 November 2014].

Mustafa Kamal Amat Misra \& Jaffary Awang. 2013. Dialog antara agama di Malaysia: Perkembangan daripada tahun 1956-2010. 'Ulum Islamiyyah Journal 11(December): 4964.

Normah Sulaiman. 2014. Interview, 15 August.

Nuredayu Omar. 2002. Pengurusan konflik antara etnik dan penduduk minoriti: Polisi dan amalan pentadbiran sesebuah negara secara umum. Jurnal Pembangunan Sosial (4\&5): 167-181.

Othman Mustapha. 2014. Interview, 9 September.

Schottmann, S.A. 2013. Sustaining interfaith dialogue: A case study from Australia. Global Change, Peace and Security 25(3): 319-324. 
The Pure Life Society. 2013. History. http://www.purelife.org.my/aboutus-history.html. [11 March 2014].

Urusetia Majlis Kebangsaan Bagi Hal Ehwal Ugama Islam Malaysia 2013. Peraturan Majlis Kebangsaan Bagi Hal Ehwal Ugama Islam Malaysia. Putrajaya: Jabatan Kemajuan Islam Malaysia.

Wan Sabri Wan Yusof \& Arfah Ab Majid. 2012. Inter religious dialogue models In Malaysia. GJAT 2(1): 7-11.

Yusri Mohammad Ramli. 2007. Dialog antara agama: Perkembangannya dalam separuh abad selepas merdeka. Dlm. Mazlan Ibrahim \& Kamarudin Salleh (pnyt.). Seminar Antarabangsa Agama \& Pembangunan III: Islam Pasca Kemerdekaan. Shah Alam: Karisma Publications. 